\title{
The Properties and Large-scale Production of L-Asparaginase from Citrobacter
}

\author{
By SHOSHANA BASCOMB*, G. T. BANKS, M. T. SKARSTEDT, \\ A. FLEMING AND K. A. BETTELHEIM \\ Department of Biochemistry, Imperial College of Science and Technology, \\ London $\mathrm{SW}_{7} 2 \mathrm{AZ}$
}

AND T. A. CONNORS

Chester Beatty Research Institute, Institute of Cancer Research, Royal Cancer Hospital, London $\mathrm{SW}_{3} 6 \mathrm{JB}$

(Received 4 December 1974; revised 3 April 1975)

\section{SUMMAR Y}

An intracellular L-asparaginase with antitumour activity was purified from a strain of Citrobacter. The optimum conditions for enzyme production by fermentation on scales up to 27001 were investigated. Highest enzyme yield was obtained in corn-steep liquor medium $\left(9.2 \%\right.$ w/v) at $37^{\circ} \mathrm{C}$. Oxygen limitation was not necessary for high enzyme yield. A total recovery of $4.3 \%$ from nucleicacid-free extract and a $180-$ fold increase in specific activity were obtained after purification. The specific activity of the purified preparation was $45 \mathrm{i} . \mathrm{u} . / \mathrm{mg}$ protein. The enzyme hydrolysed D-asparagine and L-glutamine at 7 and $5 \%$, respectively, of its activity toward L-asparagine, but L-glutaminase activity could be demonstrated only at substrate concentrations above $5 \mathrm{mM}$. The $K_{m}$ values for L-asparagine and D-asparagine were $2.6 \times \mathrm{IO}^{-5}$ and $\mathrm{I} \cdot 4 \times \mathrm{IO}^{-4}$ respectively. The anti-lymphoma activity of the enzyme was demonstrated with Gardner lymphosarcoma and was found only slightly less potent that Crasnitin, the most active asparaginase so far tested in this system.

\section{INTRODUCTION}

The effect of L-asparaginase (L-asparagine amidohydrolase, EC. 3.5.I.1) in treatment of experimental and human tumours has been studied extensively and reviewed recently (Capizzi, Bertino \& Handschumacher, 1970). The need for large quantities of enzyme for therapeutic work has promoted a search for L-asparaginase in micro-organisms, as they lend themselves to large-scale production. Occurrence of L-asparaginase in various microorganisms was reported by many workers and recently by Wade, Robinson \& Phillips (197I), Arima et al. (1972) and Imada et al. (1973). L-Asparaginase activity was found in varying quantities in different organisms, and appears to be more common among Gramnegative bacteria. Anti-tumour activity was shown by the enzymes from Escherichia coli (Mashburn \& Wriston, 1964), Serratia marcescens (Rowley \& Wriston, 1967), Erwinia carotovora (Wade et al. I968), Er. aroideae (Peterson \& Cigler, 1969), Mycobacterium tuberculosis (Reddy et al. 1969), Proteus vulgaris (Tosa et al. I97I), and by a glutaminase/ asparaginase enzyme from Achromobacter (Roberts, Holcenberg \& Dolowy, 1970) but not by L-asparaginase from Bacillus coagulans (Mashburn \& Wriston, 1964). The enzyme

* Present address: Department of Bacteriology, St Mary's Hospital Medical School, London W2 IPG. 
from $E$. coli is produced commercially and most of the clinical tests have been done with different commercial preparations of this enzyme (Clarkson et al. 1970; Tallal et al. 1970). Repeated administration of L-asparaginase to the blood stream caused hypersensitivity, ranging from mild allergic symptoms to anaphylactic shock, in 5 to $20 \%$ of patients (Cooney \& Handschumacher, 1970). To overcome this allergic response, L-asparaginases with similar anti-tumour activity but of different antigenic structure are needed to allow continued treatment of a responding but antigenically sensitive patient. So far the $E r$. carotovora enzyme has been shown in clinical trials to be a useful alternative to that of $E$. coli (Crowther, 197I) and we have continued the search for other enzymes. Although a number of papers describe the extraction of L-asparaginase (Wriston \& Yellin, 1973), only a few describe large-scale extraction procedures (Arens et al. 1970; Ho et al. 1970). This paper describes the large-scale production, purification and some of the properties of L-asparaginase from a strain of Citrobacter. Particular emphasis is placed on the problems involved in its production on a semi-industrial scale (2700 1) and its purification.

\section{METHODS}

Media. Two types of media were used: (i) Media containing different concentrations of corn-steep liquor (CSL) (Garton \& Son Ltd, London) were prepared according to Roberts, Burson \& Hill (1968). The $\mathrm{pH}$ was adjusted to $7^{\circ} \mathrm{O}$ unless otherwise stated. (ii) Yeast autolysate media to which various organic acids were added. Yeatex granules were obtained from Bovril Ltd, Burton-on-Trent, Staffordshire. The acids used were standard laboratory reagent grade from $\mathrm{BDH}$ or Hopkin and Williams Ltd. Media were prepared in tap water and the $\mathrm{pH}$ adjusted to $70^{\circ}$. Details of media are given in Table 4.

Organism. Citrobacter, Imperial College No. c6 from the Salmonella Reference Laboratory, Colindale (No. EIOI/67), showing high enzyme activity, was chosen for large-scale production.

Culture maintenance. Master cultures of Citrobacter c6 were preserved by storage in Pyrex ampoules under liquid nitrogen at $-196{ }^{\circ} \mathrm{C}$. Cultures for preservation were grown for $24 \mathrm{~h}$ at $30{ }^{\circ} \mathrm{C}$ using $6.14 \%$ (w/v) CSL medium in shaken flasks; sterile glycerol $(10 \%$, $\mathrm{v} / \mathrm{v}$ ) was added at the end of the incubation period and the mixture dispensed in $\mathrm{I} \mathrm{ml}$ quantities into sterile ampoules. The ampoules were cooled slowly to $-60{ }^{\circ} \mathrm{C}$ overnight, before immersing them quickly in liquid nitrogen.

Agar slope cultures for use in the development of laboratory inocula were obtained by removing a master culture from liquid nitrogen and allowing it to attain ambient temperature; the thawed bacterial suspension was used to inoculate nutrient agar slopes, which were incubated at $30^{\circ} \mathrm{C}$ for $24 \mathrm{~h}$ and then stored at 2 to $4{ }^{\circ} \mathrm{C}$ for a maximum period of 2 months.

Growth studies. Preliminary experiments were conducted in $500 \mathrm{ml}$ conical flasks containing $100 \mathrm{ml}$ medium sterilized by autoclaving at I2I ${ }^{\circ} \mathrm{C}$ for $20 \mathrm{~min}$. Each flask was inoculated with $2 \mathrm{ml}$ of an overnight nutrient broth culture. Incubation, unless otherwise stated, was at $37{ }^{\circ} \mathrm{C}$ for $18 \mathrm{~h}$ on a rotary shaker, operated at $200 \mathrm{rev} . / \mathrm{min}$, radius of gyration $45 \mathrm{~mm}$. Under these conditions an oxygen transfer rate of $38 \mathrm{ml}$ oxygen (at s.t.p.)/ $100 \mathrm{ml} / \mathrm{h}$ was recorded by means of the sulphite oxidation technique (Cooper, Fernstorm \& Miller, 1944).

Pilot-scale fermentations. For the development of a laboratory inoculum, the primary seed stage was first prepared in $500 \mathrm{ml}$ conical flasks containing $100 \mathrm{ml}$ of $6.14 \%(\mathrm{w} / \mathrm{v})$ CSL medium. Each flask was inoculated with a loopfull of cells derived from a refrigerated 
Table I. Fermentation conditions

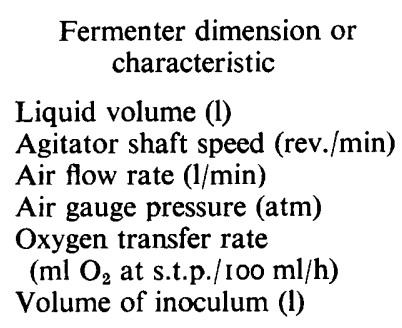

slant culture of the organism, and incubated at $30{ }^{\circ} \mathrm{C}$ for $24 \mathrm{~h}$ on a rotary shaker. Then to prepare the secondary seed stage, CSL medium ( $11 ; 6 \cdot 14 \%$, w/v) was dispensed into 41 conical flasks each fitted with a side-arm, and sterilized by autoclaving at I2I ${ }^{\circ} \mathrm{C}$ for $\mathrm{I} h$. Each flask was inoculated with $10 \mathrm{ml}$ primary seed-stage culture and incubated at $30^{\circ} \mathrm{C}$ for $\mathrm{I} 8 \mathrm{~h}$ on a rotary shaker.

Production-stage fermentations. Fermenters of conventional design, ranging from 5 to 27001 capacity, were employed. The characteristic features of the 5, 60 and 4001 fermenters were described by Banks, Mantle \& Szczyrbak (1974); the features of the 27001 fermenters were similar to those described for 4001 fermenters.

Fermenters were batched with CSL medium (6.I4 and $9.20 \%$, w/v, CSL, for seed-stage and production-stage fermentations, respectively), containing $0.01 \%(\mathrm{v} / \mathrm{v})$ polypropylene glycol antifoam (polyglycol P.2000; Dow Chemical Co. Ltd). Further polypropylene glycol was added, as necessary, during the fermentation to control foaming. Medium was always sterilized in situ with the fermenter. Five-litre vessels were sterilized by autoclaving for $\mathrm{I} \mathrm{h}$ at $\mathrm{I} 2 \mathrm{I}{ }^{\circ} \mathrm{C}$, whilst all other vessels were sterilized by live steam injection for $20 \mathrm{~min}$ at $\mathrm{I} 2 \mathrm{I}{ }^{\circ} \mathrm{C}$.

Fermentation conditions are given in Table I. Secondary seed-stage laboratory inoculum was used to initiate all 5,60 and 400 litre-scale fermentations, which were subsequently incubated at $37^{\circ} \mathrm{C}$ for up to $24 \mathrm{~h}$. Inoculum for 27001 fermentations was provided in the form of a 60 litre-scale seed-stage fermentation grown for $20 \mathrm{~h}$ at $37^{\circ} \mathrm{C}$, under conditions of low aeration. The 2700 litre-scale fermentations were terminated after $8 \mathrm{~h}$ incubation (corresponding to the time of maximum enzyme yield, see Fig. 3) by diverting oxygen from the sparger to the fermenter head, thus effectively depriving the micro-organism of oxygen, and by reducing the temperature of the fermenter contents to $5^{\circ} \mathrm{C}$ by passaging chilled water through the vessel jackets.

Automatic pH control was employed in 51 fermenters only. Control, within $\pm 0 . \mathrm{I} \mathrm{pH}$ unit, was achieved by the addition of sterile $10 \%(\mathrm{v} / \mathrm{v})$ sulphuric acid.

Dissolved oxygen concentration. A Hersch meter connected to a Teflon coil containing oxygen-free argon as the carrier gas (after Roberts \& Shepherd, I968) was used.

Oxygen consumption. Input air and exhaust gas from fermenters were dried by passage through chilled water condensers followed by silica gel. The oxygen content of the dried gasses was determined with a Servomex Paramagnetic oxygen analyser OA I84. The oxygen consumption of the culture was calculated from the difference between input and output measurements.

$\mathrm{CO}_{2}$ evolution. Exhaust gas was dried by passage through a chilled water condenser followed by anhydrous $\mathrm{CaSO}_{4}$, and the $\mathrm{CO}_{2}$ content determined by a Hilger and Watt infrared gas analyser ( $\mathrm{SC} / \mathrm{F})$. A correction for the $\mathrm{CO}_{2}$ present in input air was applied. 


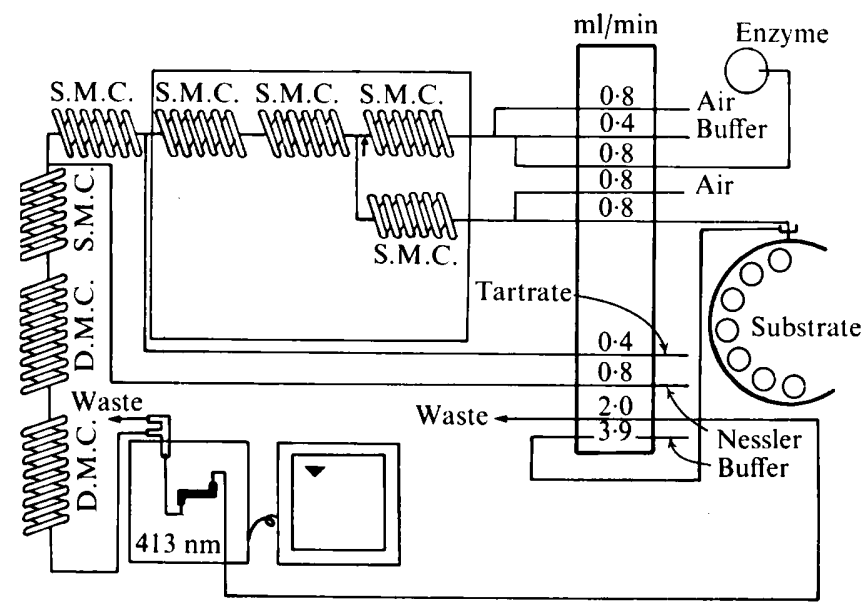

Fig. I. Manifold of automated system for kinetic studies. The final concentration of potassium borate buffer was $25 \mathrm{~mm}$. Other reagents employed were $0.3 \%$ sodium potassium tartrate and a $10 \%$ solution of Koch \& McMeekin (1924) Nessler reagent. S.M.C., single mixing coil; D.M.C., double mixing coil; $\uparrow, 20 \mathrm{ft}$ delay coil introduced for experiments studying the effect of temperature.

Total nitrogen was determined by the continuous flow method of Technicon AutoAnalyser No. N3a.

Cell counts. Total cell counts were determined with a standard haemocytometer counting chamber $(0.02 \mathrm{~mm}$ depth) with Thoma ruling. Viable cell counts were determined by the Miles \& Misra (1938) technique.

Preparation of samples for assay of enzyme activity and protein content. The cells were harvested by centrifuging $10 \mathrm{ml}$ samples for $10 \mathrm{~min}$ at $38000 \mathrm{~g}$ in an MSE highspeed centrifuge at $4{ }^{\circ} \mathrm{C}$, and resuspended in $0.05 \mathrm{M}$-potassium phosphate buffer $\mathrm{pH} 8.0$.

Samples from extraction steps (ii), (iii), (iv) and (v) (see below) were dialysed overnight at $5{ }^{\circ} \mathrm{C}$ against $0.05 \mathrm{M}$-potassium borate buffer $\mathrm{pH} 8 \cdot 0$. All samples were diluted in this buffer.

Assay of L-asparaginase, L-glutaminase and protein. The automated assay system was of the continuous-flow type and consisted of three analytical channels running simultaneously (Bascomb \& Grantham, 1975). The modified manifold differed from the above in providing the enzyme samples through the revolving sampler plate, and using only one probe and a continuous supply of substrate. For kinetic studies an automated single-channel system measuring the ammonia released after a I min incubation period was used (Fig. I). The sensitivity range was 0.05 to $0.5 \mu \mathrm{mol} \mathrm{NH}_{3} / \mathrm{ml}$, which is equivalent in this system to 0.05 to 0.5 i.u. ( $\mu \mathrm{mol} \mathrm{NH}_{3}$ released $/ \mathrm{min}$ ).

Large-scale extraction of L-asparaginase. Methods commonly used for laboratory purification of enzymes were adapted to large-scale usage. The control of temperature at all stages was of paramount importance and standard equipment was modified to achieve efficient cooling. Unless otherwise specified, the product was maintained at $4 \pm \mathrm{I}{ }^{\circ} \mathrm{C}$. The extraction steps were as follows:

(i) Harvest of cells. At the end of the fermentation the culture broth was chilled and held without agitation for $\mathrm{I} h$. The medium solids which settled were discarded with the first 501 of culture medium. Bacteria were then removed from the bulk of the culture by centrifugation in a Westfalia model SAMR 3036 operating at $4201 / \mathrm{h}$. The final volume of bac- 
terial suspension was brought up to $\mathrm{I} 501$ with $0.02 \mathrm{M}$-potassium borate buffer $\mathrm{pH} \mathrm{8.0.}$ The suspension was thoroughly mixed with a Silverson high-speed emulsifier model DX and kept for up to $66 \mathrm{~h}$.

(ii) Cell disruption. The bacteria were ruptured by passing the chilled suspension through an APV Manton-Gaulin sub-micron dispersor model $\mathrm{K}_{3}$, operating at a gauge pressure of $500 \mathrm{~atm}$ and at a rate of $250 \mathrm{l} / \mathrm{h}$. The suspension was mixed and chilled to $8{ }^{\circ} \mathrm{C}$ between passes. Maximum temperature attained during this stage was $22{ }^{\circ} \mathrm{C}$. Four passes were necessary to disrupt most of the cells and solubilize about $90 \%$ of the enzyme.

(iii) Removal of nucleic acids. $\mathrm{MnCl}_{2}$ (I M) (Rowley \& Wriston, I967) was added with vigorous agitation to the suspension at the rate of $I$ to $21 / \mathrm{min}$, to give a final concentration of $0^{\prime}$ I M. After I h mild agitation, the precipitate was removed by repeated centrifugation in a Sharples No. 6 tubular bowl centrifuge at a feed rate of $1001 / \mathrm{h}$. The volume of the supernatant was brought to 1501 with cold $0.02 \mathrm{M}$-potassium borate buffer $\mathrm{pH} 8.0$, and the temperature lowered to $0^{\circ} \mathrm{C}$. A clear supernatant was not obtained.

(iv) Acetone fractionation. A volume of acetone at $-10{ }^{\circ} \mathrm{C}$, equal to 0.28 of the volume of the supernatant of step (iii), was added slowly and with continuous stirring, temperature being maintained below $0{ }^{\circ} \mathrm{C}$. The suspension was agitated for $30 \mathrm{~min}$ and the temperature lowered to $-5{ }^{\circ} \mathrm{C}$. The precipitate (about $17 \mathrm{~kg}$ ) was removed by centrifugation and discarded. Temperature at this stage never exceeded $2{ }^{\circ} \mathrm{C}$. A volume of acetone at $-\mathrm{I} 2{ }^{\circ} \mathrm{C}$, corresponding to 0.62 of the original volume, was added to the completely clear supernatant held at $-5{ }^{\circ} \mathrm{C}$. The suspension was gently agitated for $30 \mathrm{~min}$ at $-10{ }^{\circ} \mathrm{C}$ and centrifuged. The temperature during this stage was rigorously controlled at $-10^{\circ} \mathrm{C}$. The supernatant was discarded and the precipitate (about $7 \mathrm{~kg}$ ) resuspended immediately in 401 (total volume) of cold $0.05 \mathrm{M}$-potassium borate buffer $\mathrm{pH} 8 \cdot 0$. The suspension stood overnight at $5{ }^{\circ} \mathrm{C}$, and was then centrifuged. The volume of the supernatant was brought up to $40 \mathrm{l}$ with the same buffer.

(v) Ammonium sulphate fractionation. The fraction of protein precipitating between $0.2 \mathrm{I}$ and $0.52 \mathrm{~g}$ crystalline ammonium sulphate (general purpose reagent) $/ \mathrm{ml}$ (about $2.5 \mathrm{~kg}$ ) was dissolved in $0.05 \mathrm{M}$-potassium borate buffer $\mathrm{pH} 8.0$ and brought to a total volume of 5 l. Some finely divided material remained in suspension.

(vi) DEAE column fractionation. The solution from step (v) was ultrafiltered by a Sartorius membrane filter No. I2I 34 (pore size $15 \mathrm{~nm}$ ) until the ammonium sulphate concentration was below $0.01 \mathrm{M}$. The dialysed filtrate was brought to a volume of 201 and allowed to flow at a rate of $4 \mathrm{l} / \mathrm{h}$ through an 81 column $(15 \times 45 \mathrm{~cm})$ of DEAE cellulose (grade DE-I I ; Whatman Biochemicals, Maidstone, Kent), and equilibrated on the column by washing with 2 to 3 volumes of $0.05 \mathrm{M}$-potassium borate buffer $\mathrm{pH} 8 \cdot 0$. The column was eluted with a 4010 to $0.3 \mathrm{M}$ gradient of $\mathrm{KCl}$ in borate buffer. The effluent was collected in $800 \mathrm{ml}$ fractions and the most active fractions combined.

(vii) Hydroxylapatite-brushite column fractionation. Ammonium chloride was added to the combined fractions from step (vi) to give a final concentration of $0 . \mathrm{I}$ M. A 2 l column $(7.5 \times 40 \mathrm{~cm})$ containing $500 \mathrm{ml}$ of a packed calcium hydroxylapatite suspension mixed with I $500 \mathrm{ml}$ of a packed brushite suspension (Skarstedt \& Bascomb, I974) was equilibrated with 3 column volumes of 0.05 M-potassium borate buffer containing 0.1 M-ammonium chloride. The combined fractions were loaded at a rate of $250 \mathrm{ml} / \mathrm{h}$, the column washed with a further column volume of $0.1 \mathrm{M}$-ammonium chloride in potassium borate buffer $\mathrm{pH} 8 \cdot 0$, and eluted with a 610 to $0.3 \mathrm{M}$-potassium phosphate gradient in the borate buffer containing $0^{\circ} \mathrm{I} \mathrm{M}$-ammonium chloride $(\mathrm{pH} 8 \cdot 0$ ). The effluent was collected in $\mathrm{I} 20 \mathrm{ml}$ fractions and the most active combined. 
(viii) Sephadex G-200 column fractionation. The combined fractions from step (vii) were placed in an Amicon ultrafiltration cell, $400 \mathrm{ml}$ capacity, fitted with a PM-IO membrane, and the volume reduced to $50 \mathrm{ml}$ at an applied gauge pressure of nitrogen of $\mathrm{I} \cdot 7 \mathrm{~atm}$. The sample was then applied to three $67 \times 77 \mathrm{~cm}$ columns arranged in series, each containing $1400 \mathrm{ml}$ Sephadex G-200 (Pharmacia) supported by glass beads (Sachs \& Painter, 1972) and equilibrated with $0.05 \mathrm{M}$-potassium borate buffer $\mathrm{pH} 8 \cdot 0$. The column was eluted with the same buffer at a rate of $100 \mathrm{ml} / \mathrm{h}$. The first eluate $(1800 \mathrm{ml})$ was discarded. The further eluate $(2400 \mathrm{ml})$ was collected in $60 \mathrm{ml}$ fractions, and the most active fractions combined.

(ix) Sterilization and lyophilization. The combined fractions from step (viii) were ultrafiltered as above, and the volume reduced to $20 \mathrm{ml}$. This solution was applied to an I I00 $\mathrm{ml}$ column of Sephadex G-25, washed and eluted with distilled water adjusted to $\mathrm{pH} 8 \cdot 0$ at a flow rate of $225 \mathrm{ml} / \mathrm{h}$. The first eluate $(500 \mathrm{ml})$ was discarded. The next eluate (I IO ml) was collected and sterilized by passage through a Millipore filter (pore size $0.22 \mu \mathrm{m}$ ). The resulting solution was shell-frozen and lyophilized under a pressure of less than 0.005 $\mathrm{mmHg}$. The dry material was removed aseptically and stored in a sterile container at $-15{ }^{\circ} \mathrm{C}$ until used in the tests for anti-tumour activity.

Molecular weight determination. A column of Sephadex G-200 measuring $\mathrm{I} \cdot 8 \times 62 \mathrm{~cm}$ $(\mathrm{I} 56 \mathrm{ml})$ was prepared and calibrated using the following proteins: yeast $\beta$-D-fructosidase (270000 daltons), yeast alcohol dehydrogenase (145000 daltons), Clostridium histolyticum collagenase (I07000 daltons), horseradish peroxidase (40000 daltons) and denatured lysozyme (I 4400 daltons). For each determination, the fraction number was normalized with blue dextran, which was always considered to elute at fraction $25 \cdot 2$. The sample consisted of $0.5 \mathrm{ml}$ enzyme, and fractions of 36 drops were collected under conditions of gravity-dependent flow at a rate of $15 \mathrm{ml} / \mathrm{h}$.

Assay of biological activity. The Gardner lymphosarcoma (Connors \& Jones, 1970) was obtained from Dr J. D. Broome in I 968 and was routinely passaged in ascitic form by the intraperitoneal injection of about $5 \times 10^{6}$ cells in $0.1 \mathrm{ml}$ of $0.90 \%(\mathrm{w} / \mathrm{v}) \mathrm{NaCl}$, and in solid form by the subcutaneous implantation of tumour fragments. Solid tumours were also obtained from the ascites cells by subcutaneous injection. From time to time the ascites line was discontinued and new ascitic tumour obtained by intraperitoneal injection of a suspension of the solid tumour. The tumour was passaged in CBA/LAC mice, not in the $\mathrm{C}_{3} \mathrm{H}$ strain in which it was originally induced.

For routine screening of asparaginase preparations, groups of mice received an intraperitoneal injection of approximately $5 \times 10^{6}$ ascites cells on day zero and then on day 3 were treated with the agent under test, administered intraperitoneally in $0 . \mathrm{I} \mathrm{ml}$ saline. Drug treatment was repeated daily for a total of 5 days. Several dose levels of the test agent were used and the survival times of treated groups compared with the survival times of controls. Since there is an inverse relationship between survival time and number of viable cells injected, the percentage increase in life span (\% i.l.s.) of treated groups, compared with controls, is a direct measure of tumour-cell kill (Connors \& Jones, 1970). 


\section{RESULTS AND DISCUSSION}

\section{Choice of strain}

Over a thousand strains were screened for L-asparaginase activity by the method of Bettelheim, Kissin \& Thomas (1970). These included: recognized serotypes of $E$. coli and Salmonella, identified strains of species of enterobacteria and other rod-shaped Gramnegative bacteria, and micrococci, all from the Reference Laboratories in the Central Public Health Laboratory, Colindale; E. coli strains from the Pathology Department, University College Hospital, London; Salmonella strains from Nationale Salmonella Zentrale, Hygiene-Institute, Hamburg; a collection of Gram-negative and Gram-positive strains isolated from soil and a few strains recently isolated from various environmental sources. An atypical Citrobacter, Imperial College strain $\mathrm{c} 6$, was chosen for large-scale production of asparaginase.

\section{Identity of strain}

Imperial College strain c6, a Gram-negative rod-shaped bacterium, gave positive results in the following standard tests: decarboxylation of arginine and ornithine; growth on MacConkey agar and on Simmons' citrate agar (Oxoid); motility at $37^{\circ} \mathrm{C}$; presence of catalase, nitrate reductase and urease; production of acid from adonitol, arabinose and lactose, of acid and gas from glucose and of indole and $\mathrm{H}_{2} \mathrm{~S}$ (as tested by lead acetate paper); utilization of malonate. It was fermentative in the Hugh \& Leifson oxidation-fermentation test. It gave negative results in decarboxylation of lysine, production of acid from starch and sucrose, oxidation of gluconate, liquefaction of gelatin in I4 days, presence of oxidase, PPA and Voges Proskauer tests. Variable results were obtained with the TSI test. These results are very similar to those described for Citrobacter matrix biotype II (Bascomb et al. 1973).

\section{Growth and enzyme production}

Effects of medium. The effect of nitrogen source, at $0 \cdot 2 \% \mathrm{~N}$, on growth and L-asparaginase production was studied in $500 \mathrm{ml}$ flasks using six commercial products available for largescale fermentations (Table 2). Growth as measured by viable count was best on yeast autolysate but more enzyme was produced with CSL $(5 \cdot 7 \%$ w/v). The optimum concentration of CSL for growth and enzyme production was tested in 51 fermenters. Highest yield of bacterial protein (Table 3) was obtained at the highest CSL concentration, while maximum enzyme production was at 8.6 to $9.8 \%(\mathrm{w} / \mathrm{v})$.

CSL medium formed a precipitate during heat sterilization, and was therefore not desirable for growing bacteria intended for extraction of intracellular enzymes. Also, variability of enzyme yields between different large-scale fermentations was too high. The effect on growth and enzyme production of media containing Yeatex plus acetic, citric or lactic acids at concentrations of $C$ and $N$ equal to those in $9.2 \%(w / v) C S L$, was tested (Table 4). The medium containing Yeatex plus lactic acid yielded enzyme activities greater than Yeatex plus acetic or citric acid, but much smaller than CSL medium. Experiments with various concentrations of Yeatex plus lactic acid showed that $3 \%(\mathrm{w} / \mathrm{v})$ Yeatex plus $0.9 \%(\mathrm{v} / \mathrm{v})$ lactic acid may produce enzyme in yields similar to those achieved in CSL, but at ten times the cost.

Effects of temperature. Experiments with 601 fermenters containing $9.2 \%(\mathrm{w} / \mathrm{v}) \mathrm{CSL}$ medium, grown for $24 \mathrm{~h}$ at 24,27 and $37^{\circ} \mathrm{C}$, showed (Fig. 2) that the cell yield was similar at the three temperatures but that the highest enzyme activity was obtained at $37^{\circ} \mathrm{C}$. At $37^{\circ} \mathrm{C}$, increase in enzyme activity paralleled the increase in protein during the 
Table 2. Effect of different nitrogen sources on the growth and L-asparaginase production of Citrobacter $\mathrm{c} 6$

The dry commercial preparations were dissolved in distilled water to a concentration of $0.2 \% \mathrm{~N}$ and the $\mathrm{pH}$ adjusted to $7 \cdot 0$. Portions $(75 \mathrm{ml})$ of medium in $500 \mathrm{ml}$ conical flasks were autoclaved at $12{ }^{\circ} \mathrm{C}$ for $20 \mathrm{~min}$. Each flask was inoculated with a loopful of cells derived from an overnight nutrient-broth culture and incubated at $37^{\circ} \mathrm{C}$ on a rotary shaker for $24 \mathrm{~h}$.

\begin{tabular}{lcc}
\multicolumn{1}{c}{ Medium } & $10^{-9} \times$ Viable cells $/ \mathrm{ml}$ & $\begin{array}{c}\text { L-asparaginase } \\
\text { (i.u. } / \mathrm{ml})\end{array}$ \\
Soybean meal & 0.96 & 0 \\
Ground-nut meal & $\mathrm{I} \cdot 00$ & 0 \\
Pharmamedia & $\mathrm{I} \cdot 54$ & 0 \\
Scotaferm (Borthwick, Glasgow) & $2 \cdot 20$ & 0.07 \\
Yeast autolysate (Yeatex) & $1 \mathrm{I} \cdot 00$ & 0.47 \\
Corn steep liquor & $7 \cdot 00$ & 0.88
\end{tabular}

Table 3. Effect of CSL concentration on the growth and L-asparaginase production of Citrobacter $\mathrm{c} 6$

Bacteria were grown in 51 fermenters at $37^{\circ} \mathrm{C}$. Samples ( $10 \mathrm{ml}$ ) were taken at $3 \mathrm{~h}$ intervals during a $24 \mathrm{~h}$ fermentation and the maximum values obtained.

$\begin{array}{ccc}\begin{array}{c}\text { CSL concentration } \\ (\%, \mathrm{w} / \mathrm{v})\end{array} & \begin{array}{c}\text { Maximum } \\ \text { bacterial protein } \\ (\mathrm{mg} / \mathrm{ml})\end{array} & \begin{array}{c}\text { Maximum } \\ \text { L-asparaginase } \\ \text { (i.u. } / \mathrm{ml})\end{array} \\ 6 \cdot \mathrm{I} 4 & \mathrm{I} \cdot 8 \mathrm{I} & \mathrm{I} \cdot 24 \\ 7.37 & 2 \cdot 50 & \mathrm{I} \cdot 27 \\ 8.60 & 2 \cdot 9 \mathrm{I} & \mathrm{I} \cdot 33 \\ 9 \cdot 82 & 2.60 & \mathrm{I} \cdot 33 \\ \mathrm{II} \cdot 05 & 3.3 \mathrm{I} & \mathrm{I} \cdot 26 \\ \mathrm{I2} \cdot 28 & 3.34 & 0.6 \mathrm{I}\end{array}$

Table 4. Effect of organic acids on the growth and L-asparaginase production of Citrobacter $\mathrm{C} 6$

Bacteria were grown in 51 fermenters at $37^{\circ} \mathrm{C}$. Media were prepared in tap water, with the $\mathrm{pH}$ adjusted to $7 \cdot 0$. Samples $(10 \mathrm{ml})$ were taken at $3 \mathrm{~h}$ intervals during a $24 \mathrm{~h}$ fermentation and the maximum values obtained.

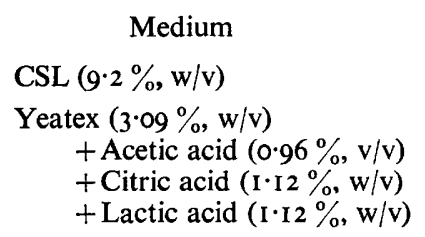

$\begin{gathered}\text { Maximum } \\ \text { bacterial protein } \\ (\mathrm{mg} / \mathrm{ml})\end{gathered}$
$\mathrm{I} \cdot 93$

$\mathrm{I} \cdot \mathrm{I} 8$
$\mathrm{I} \cdot \mathbf{2 I}$
$\mathrm{I} \cdot 72$

Maximum
L-asparaginase
(i.u./ml)
I.03

0.37
0.41
0.59

exponential phase but during the stationary phase enzyme activity decreased. In production, bacteria were therefore harvested at the beginning of the stationary phase.

Effects of $\mathrm{pH}$. Application of $\mathrm{pH}$ control during the fermentation at values between 6.0 and 8.0 showed that bacterium and enzyme yields were small at $\mathrm{pH} 6 \cdot 0$. Above this value growth was similar to that of the control fermentation; however, L-asparaginase production at $\mathrm{pH}$ values below 7.5 was markedly less than in fermentations without $\mathrm{pH}$ control in which the $\mathrm{pH}$ rose from $7 \cdot 0$ to $8 \cdot 5$. 

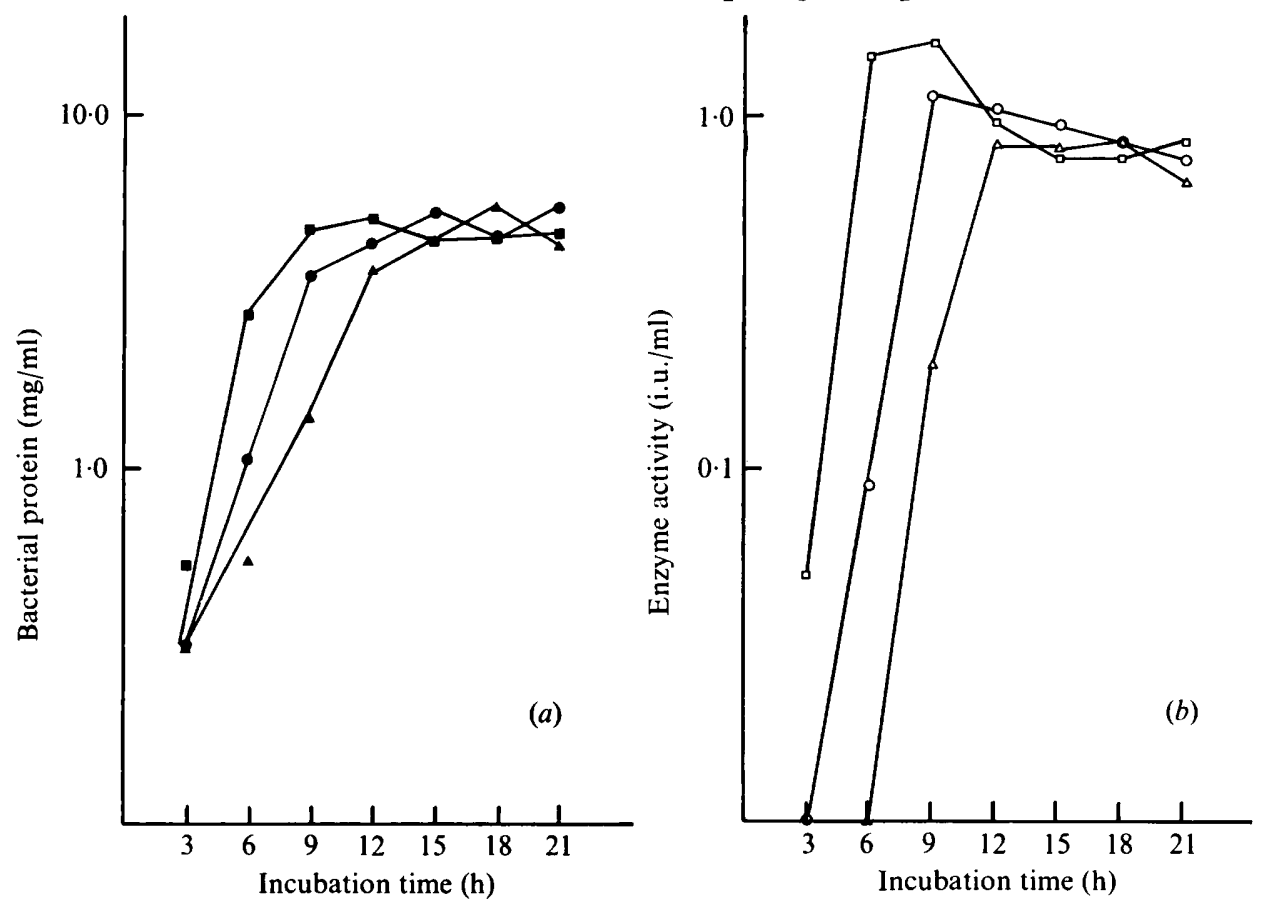

Fig. 2. Effect of temperature on the growth and L-asparaginase production of Citrobacter c6. Bacteria were grown in $60 \mathrm{l}$ fermenters. Samples $(10 \mathrm{ml})$ were taken at $3 \mathrm{~h}$ intervals and assayed by an automated analytical system as described. (a) Protein content of bacteria, with fermentation at $(\boldsymbol{\square}) 37^{\circ} \mathrm{C},(\bullet) 27^{\circ} \mathrm{C}$, and $(\Delta) 24^{\circ} \mathrm{C}$. (b) L-Asparaginase activity, with fermentation at $(\square)$ $37^{\circ} \mathrm{C}$, (○) $27^{\circ} \mathrm{C}$, and $(\triangle) 24^{\circ} \mathrm{C}$.
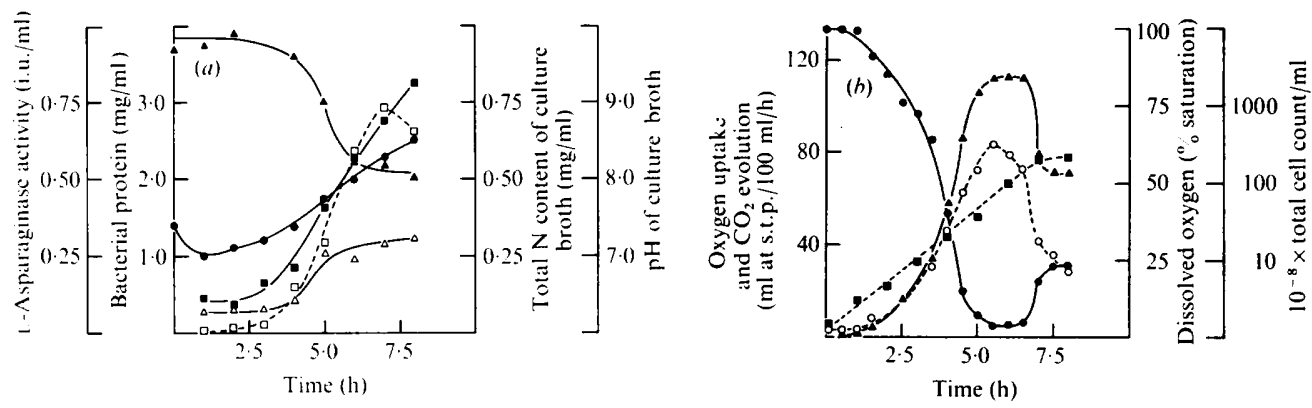

Fig. 3. The course of a typical 3000 litre-scale production-stage fermentation. (a) $\square$, Bacterial protein; $\square$, total asparaginase activity; $\Delta$, total glutaminase activity; $\boldsymbol{\Delta}$, total nitrogen content of medium; $\boldsymbol{\bullet}, \mathrm{pH}$. (b) $\boldsymbol{\bullet}$, Dissolved-oxygen concentration; $\boldsymbol{\Delta}$, total oxygen uptake; 0 , total carbon dioxide evolution; $\mathbf{a}, \log$ cell count.

\section{Large-scale fermentation}

The course of a typical 2700 litre-scale production-stage fermentation is illustrated graphically in Fig. 3. There was a progressive rise in $\mathrm{pH}$ throughout the fermentation, from 7.0 to 8.5 . The amount of nitrogen utilized $(0.5 \mathrm{mg} / \mathrm{ml})$ corresponded well with the final cell dry weight recorded $(5 \cdot \mathrm{mg} / \mathrm{ml}$ ). Exponential growth (as determined by bacterial protein or bacterial dry weight measurements) occurred during the first $5 \mathrm{~h}$ of the fermentation, after which the dissolved oxygen concentration fell below $5 \%$ of the saturation 


\section{Table 5. Effect of aeration on the growth and L-asparaginase production of Citrobacter $\mathrm{c} 6$}

Bacteria were grown in 51 fermenters at $37^{\circ} \mathrm{C}$. Samples ( $\left.10 \mathrm{ml}\right)$ were taken at $3 \mathrm{~h}$ intervals during a $30 \mathrm{~h}$ fermentation and maximum values obtained.

\begin{tabular}{|c|c|c|c|c|}
\hline \multirow{2}{*}{$\begin{array}{l}\text { Agitator } \\
\text { shaft speed } \\
\text { (rev./min) }\end{array}$} & \multirow{2}{*}{$\begin{array}{l}\text { Impeller } \\
\text { diameter } \\
(\mathrm{cm})\end{array}$} & \multirow{2}{*}{$\begin{array}{c}\text { Aeration } \\
\text { efficiency* } \\
\left(\mathrm{h}^{-1}\right)\end{array}$} & \multicolumn{2}{|c|}{ Maximum asparaginase yield $\dagger$} \\
\hline & & & i.u./ml & i.u./mg protein \\
\hline 350 & $5 \cdot 0$ & $18 \cdot 0$ & $0.77(27) \ddagger$ & $0.90(27)$ \\
\hline 400 & $5 \cdot 0$ & $26 \cdot 6$ & $1 \cdot 06(30) \ddagger$ & $0.88 \quad(7)$ \\
\hline 350 & $6 \cdot 4$ & $60 \cdot 8$ & $\mathrm{I} \cdot 06(2 \mathrm{I})$ & 0.9 I (6) \\
\hline 400 & $6 \cdot 4$ & $93 \cdot 0$ & $\mathrm{I} \cdot 04(\mathrm{I} 2)$ & $0.84(6)$ \\
\hline 350 & $7 \cdot 8$ & 163 & $\mathrm{I} \cdot 03(\mathrm{I} 2)$ & $0.84 \quad(5)$ \\
\hline 400 & $7 \cdot 8$ & $25 I$ & $0.99 \quad(9)$ & $0.52(6)$ \\
\hline
\end{tabular}

value, suggesting that the oxygen supply became limiting at this stage; thereafter, a $2 \mathrm{~h}$ period of approximately linear growth was observed, total oxygen uptake remaining constant throughout. Total L-asparaginase activity increased rapidly after $3 \mathrm{~h}$ to a final value of $0.73 \mathrm{i} . \mathrm{u} . / \mathrm{ml}$ culture fluid after $7 \mathrm{~h}$. Glutaminase activity also increased throughout the fermentation, though the increase was negligible during the period of presumed oxygen limitation. During the same period L-asparaginase activity more than doubled, with the result that the specific activity of L-asparaginase and the L-asparaginase/L-glutaminase ratio increased as the fermentation progressed. After $7 \mathrm{~h}$, there was a sudden drop in oxygen consumption and a rise in dissolved oxygen concentration, whilst both cell multiplication and asparaginase production ceased.

Since, in a normal production-stage fermentation, the oxygen supply appeared to become limiting, causing a change from exponential to linear growth, and a considerable amount of L-asparaginase synthesis occurred during the period of presumed oxygen limitation, it was considered desirable to investigate the effect of aeration on enzyme production. Initial experiments were conducted on the 51 fermenter scale with $6 \cdot 14 \%(\mathrm{w} / \mathrm{v})$ CSL medium at $37^{\circ} \mathrm{C}$. Culture aeration was varied by altering the agitator shaft speed and impeller diameter, both of which factors are known to have a profound effect upon oxygen transfer rates under oxygen-limiting conditions. Culture aeration had little effect upon the ultimate yields of L-asparaginase achieved (Table 5); however, aeration had a profound effect upon the rate of fermentation. Specific enzyme activity was depressed at the highest aeration efficiency value, 25 $\mathrm{I} \mathrm{h}^{-1}$. A single fermentation was conducted on this scale under anaerobic conditions (by gassing with nitrogen); no significant growth or L-asparaginase production occurred under these conditions.

Two further experiments were carried out, each using $2 \times 4001$ fermenters (Table 6). One fermentation was operated under standard conditions, whilst conditions of high aeration were employed for the other fermentation to avoid oxygen limitation. In the first experiment oxygen supply did become limiting for a short period (about $30 \mathrm{~min}$ ) in the fermenter employing high aeration. In the second experiment, oxygen-limitation conditions were completely avoided. The results indicated that conditions of oxygen limitation are not necessary for good enzyme yield; however, the specific enzyme activity was greater under conditions of lower oxygen supply.

Schwartz, Reeves \& Broome (1966) and Cedar \& Schwartz (1968) claimed that production 
Table 6. Effect of aeration on the growth and L-asparaginase production of Citrobacter $\mathrm{c} 6$

Bacteria were grown in 4001 fermenters. Samples $(10 \mathrm{ml})$ were taken at $3 \mathrm{~h}$ intervals during a $24 \mathrm{~h}$ fermentation and the maximum values obtained.

\begin{tabular}{|c|c|c|c|c|c|}
\hline \multirow{2}{*}{$\begin{array}{l}\text { Agitator } \\
\text { shaft speed } \\
\text { (rev./min) }\end{array}$} & \multirow{2}{*}{$\begin{array}{l}\text { Impeller } \\
\text { diameter } \\
(\mathrm{cm})\end{array}$} & \multirow{2}{*}{$\begin{array}{l}\text { Maximum } \\
\text { oxygen uptake } \\
\left(\mathrm{ml} \mathrm{O} \mathrm{O}_{2} \text { at }\right. \\
\text { s.t.p. } / \mathrm{I} 00 \mathrm{ml} / \mathrm{h})\end{array}$} & \multirow{2}{*}{$\begin{array}{l}\text { Oxygen } \\
\text { limitation }\end{array}$} & \multicolumn{2}{|c|}{$\begin{array}{c}\text { Maximum asparaginase } \\
\text { yield* }\end{array}$} \\
\hline & & & & i.u. $/ \mathrm{ml}$ & i.u./mg proteir \\
\hline \multicolumn{6}{|l|}{ Expt I } \\
\hline I53 & $28 \cdot 5$ & & + & $0.87(9)$ & 0.31 (9) \\
\hline 306 & $28 \cdot 5$ & 156 & \pm & $0.60(7)$ & $0.21(6)$ \\
\hline \multicolumn{6}{|l|}{ Expt 2} \\
\hline 153 & $28 \cdot 5$ & IOI & $t$ & $0.83(9)$ & $0.28(9)$ \\
\hline 306 & $32 \cdot 5$ & 153 & - & $0.67(7)$ & $0.19(7)$ \\
\hline
\end{tabular}

* The times (h) at which the yields were maximum are given in parentheses.

Table 7. Purification of $\mathrm{L}$-asparaginase from Citrobacter $\mathrm{C} 6$

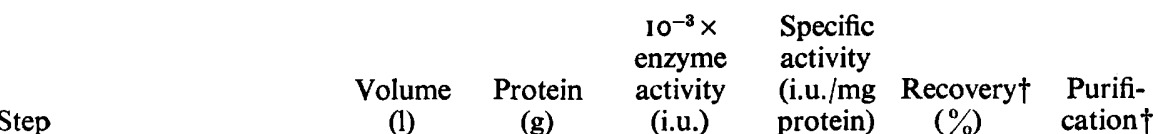

\begin{tabular}{|c|c|c|c|c|c|c|}
\hline \\
\hline \multicolumn{7}{|l|}{$\begin{array}{l}\text { (two enzymes present) } \\
\text { Ruptured cells }\end{array}$} \\
\hline (two enzymes present)* & I50 & 6150 & 1410 & 0.24 & - & - \\
\hline $\mathrm{MnCl}_{2}$ supernatant* & 150 & 5270 & 790 & 0.25 & 100 & - \\
\hline Acetone precipitation* & 40 & 534 & 529 & 0.99 & 67 & $\times 4$ \\
\hline Ammonium sulphate precipitation & & & & & & \\
\hline and dialysis* & I0 & 160 & 273 & $\mathrm{I} \cdot 88$ & 35 & $\times 7 \cdot 5$ \\
\hline $\begin{array}{l}\text { DEAE-I I column fractionation } \\
\text { HAP } \pm \text { column fractionation in }\end{array}$ & 5.6 & 54 & 197 & 3.65 & 25 & $\times 15 \cdot 0$ \\
\hline $\begin{array}{l}\mathrm{O} \cdot \mathrm{I} \mathrm{M}-\mathrm{NH}_{4} \mathrm{Cl} \\
\text { Sephadex G-200 column }\end{array}$ & 0.58 & $6 \cdot 0$ & 132 & $2 I \cdot 90$ & 17 & $\times 88 \cdot 0$ \\
\hline fractionation and lyophilization & (750 mg) & 0.75 & 34 & $45 \cdot 28$ & $4 \cdot 3$ & $\times 18 \mathrm{I} \cdot$ \\
\hline
\end{tabular}

of L-asparaginase II was stimulated more than Ioo-fold when $E$. coli $\mathrm{KI} 2$ was grown anaerobically under conditions where amino acids were utilized as carbon source. In their experiments, bacteria were allowed to multiply under aerobic conditions then transferred to anaerobic conditions. Increase in enzyme activity was detected $20 \mathrm{~min}$ after the transfer.

A set of experiments in 51 fermenters with $9 \cdot 2 \%(\mathrm{w} / \mathrm{v})$ CSL medium was conducted to investigate this effect on Citrobacter c6. Anaerobic conditions were introduced after 4 and $8 \mathrm{~h}$ with and without the addition of $0.5 \%$ glucose; no growth or enzyme synthesis occurred during anaerobiosis. Addition of glucose at 4 or $8 \mathrm{~h}$ did not change the effect of anaerobiosis.

Unlike the situation with E. coli $\mathrm{KI} 2$, the production of L-asparaginase by Citrobacter c6 grown in CSL medium was not stimulated by oxygen deprivation.

\section{Large-scale extraction of $\mathrm{L}$-asparaginase}

A summary of the results obtained during purification of the enzyme from a typical 27001 fermentation is given in Table 7.

The presence of $\mathrm{MnCl}_{2}$ or acetone or more than $2 \mathrm{mM}$-ammonia in assay samples inter- 
fered with the Nessler reaction, used for assay of enzyme activity; therefore, samples from certain extraction stages had to be dialysed before assay. However, Rowley \& Wriston (1967) reported loss of enzyme activity during dialysis at these stages of the purification and we noted similar effects. Moreover, the crude extract of Citrobacter c6 contained two L-asparaginases separable by DEAE-I I column fractionation, one of which was sensitive to $\mathrm{MnCl}_{2}$ treatment; the one we were purifying was resistant. Calculations of the recovery of enzyme at later stages were therefore based on the activity surviving $\mathrm{MnCl}_{2}$ and dialysis treatments.

The use of acetone for extraction on such a large scale was made possible by controlling the temperature rigorously at all stages of the fractionation, achieved by supplying ethylene glycol to the jackets of all vessels and pipes and to the cooling coil of the centrifuge, and by insulating all equipment extensively. The enzyme recovery under these conditions was 67 to $70 \%$ of the nucleic acid-free material. Much of the enzyme activity which was not recovered in the second acetone precipitate was detected in either the first acetone precipitate or the second acetone supernatant. The enzyme activity discarded amounted to $16 \%$ of the original, bringing the accountable enzyme recovery from the acetone step to $83 \%$. This procedure could be generally applicable to large-scale purification of other enzymes.

The six-fold increase in specific activity obtained by hydroxylapatite fractionation was due to the presence of $0.1 \mathrm{M}-\mathrm{NH}_{4} \mathrm{Cl}$ in all solutions, causing a shift of the elution position of L-asparaginase away from the co-fractionating impurities (Skarstedt \& Bascomb, 1974). This improvement is also generally applicable, since all enzymes have one or more small molecules to which they are specifically sensitive, whether the small molecule is a substrate, an activator or an inhibitor. In our experiments, the small ion used, $\mathrm{NH}_{4}{ }^{+}$, is a mild reversible inhibitor.

An overall purification of $180-$ fold, with a yield of $4.3 \%$, was obtained in the experiment detailed in Table 7. The specific activity of the final product in the most successful experiment was $79 \mathrm{i} . \mathrm{u} . / \mathrm{mg}$ protein. Arens et al. (1970), working with equivalent volumes of culture broth, obtained $4.5 \%$ recovery but only a roo-fold purification.

\section{Properties of the purified enzyme}

Temperature dependence. The effect of temperature on enzyme activity was studied on the modified analytical system where enzyme reaction time was I min (Fig. 4). Maximum enzyme activity occurred at $52{ }^{\circ} \mathrm{C}$. Enzyme activity at $37{ }^{\circ} \mathrm{C}$, the physiological temperature at which the enzyme is expected to function during therapy, is $79 \%$ of the maximum. Similar behaviour was reported for L-asparaginase from other bacterial sources (Jayaram, Ramakrishnan \& Vaidyanatham, 1968; Cooney \& Davis, I970; Law \& Wriston, I97I; Tosa et al. 1972).

$p H$ dependence. The effect of $\mathrm{pH}$ on enzyme activity is shown in Fig. 5. Maximum activity occurred over the whole range from $\mathrm{pH} 8$ to II. A similar pattern is shown for Lasparaginase activity of glutaminase/asparaginase enzyme from Achromobacter (Roberts, Holcenberg \& Dolowy, 1972). Both enzymes show a broader maximum than is reported for L-asparaginases from other sources (Wriston, I97I).

Molecular weight. This was determined by the elution position on a Sephadex G-200 column and corresponded to a molecular weight of 166000 daltons, which is higher than those reported for L-asparaginase from E. coli в (I $33000 \pm 5000$ daltons; Ho et al. 1970), Er. carotovora (I35000 \pm 10000 daltons; Cammack, Marlborough \& Miller, 1972), and from B. coagulans (86000 daltons; Law \& Wriston, 197I). A molecular weight of 17 I 000 


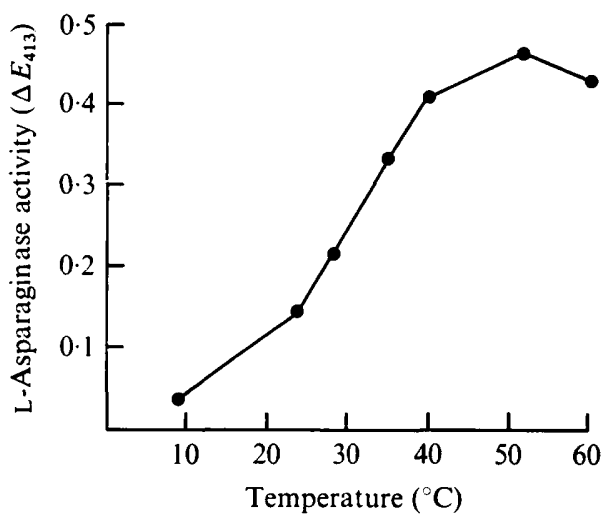

Fig. 4

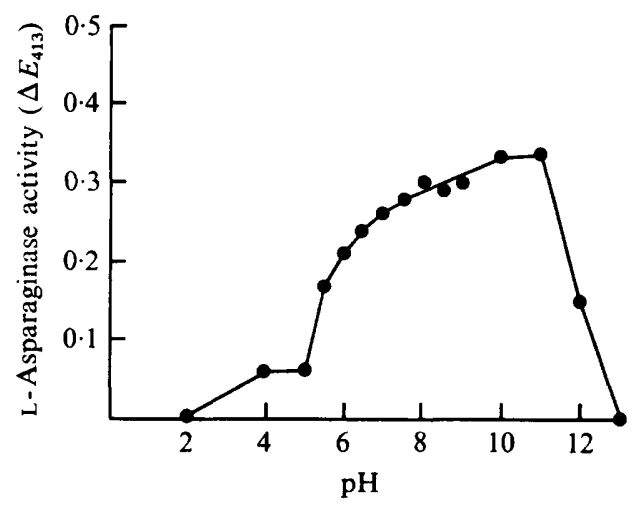

Fig. 5

Fig. 4. Effect of temperature on the activity of L-aspara ginase from Citrobacter c6. The purified lyophilized preparation was assayed by the automated kinetic analytical system, reaction time I min. Concentrations in the reaction mixture were $13 \mathrm{~mm}$ L-asparagine, and $25 \mathrm{~mm}$-potassium phosphate buffer $\mathrm{pH} 8 \cdot 0$.

Fig. 5. Effect of $\mathrm{pH}$ on the activity of L-asparaginase from Citrobacter c6. The purified lyophilized preparation was assayed by the automated kinetic analytical system, reaction time 1 min. Concentrations in the reaction mixture were $13 \mathrm{mM}$ L-asparagine, and $25 \mathrm{~mm}$-citrate-phosphateborate buffer.

daltons was reported for L-asparaginase from Fusarium tricinctum (R. W. Sheetz, as quoted by Wriston, I97I).

Enzyme specificity. The substrate specificity of the purified freeze-dried enzyme was determined with the analytical system where enzyme reaction time was $15 \mathrm{~min}$. The enzyme catalyses the hydrolysis of L-asparagine, D-asparagine and L-glutamine. The activities towards D-asparagine and L-glutamine were $7 \cdot 4$ and $5 \%$, respectively, of the activity towards L-asparagine. However, L-glutaminase activity could be demonstrated only at substrate concentrations above $5 \mathrm{~mm}$. No ammonia was released from L-alanine, adenosine, L-aspartic acid, cytidine, L-glutamic acid, L-leucine, L-methionine, L- $\beta$-phenylalanine, succinamic acid, L-serine, L-threonine, L-tryptophane or urea.

Kinetic studies. A $K_{m}$ of $2.6 \times 10^{-5} \mathrm{M}$ was found for the hydrolysis of L-asparagine by purified enzyme by the modified analytical system (reaction time I min) and the Hofstee (I959) plot. This is comparable with the $K_{m}$ found for enzymes from $E$. coli B $\left(\mathrm{I} \cdot 25 \times \mathrm{IO}^{-5}\right.$; Ho et al, 1970), Er. carotovora (1.0 $\times 10^{-5}$; Howard \& Carpenter, 1972) and P. vulgaris $\left(2.6 \times 10^{-5}\right.$; Tosa et al. 1972), and lower than S. marcescens (1 $\times 10^{-4} ;$ Wriston, 1971$)$. The hydrolysis of $D$-asparagine was determined by the normal analytical system (reaction time I $5 \mathrm{~min}$ ). A $K_{m}$ value of $\mathrm{I} \cdot 4 \times 10^{-4} \mathrm{M}$ was found, showing a much lower affinity of the enzyme for this compound.

Anti-lymphoma activities. Table 8 is the result of a comparative test between the effects of a Bayer L-asparaginase (Crasnitin) on the growth of the Gardner lymphosarcoma, and L-asparaginase preparation from Citrobacter $\mathrm{C6}$. The latter is curative at a dose level of 80 i.u. $/ \mathrm{kg}$ and only slightly less potent than Crasnitin, which is the most active asparaginase so far tested in this system. It also has no obvious toxicity at the highest dose so far used (7500 i.u. $/ \mathrm{kg}$ ). Factors that might affect the anti-lymphoma activity of L-asparaginase include $\mathrm{pH}$ optimum, $K_{m}$ value and the half-life of the enzyme in the host (Wriston, I97I; Wriston \& Yellin, 1973). The $\mathrm{pH}$ optimum for Citrobacter L-asparaginase is slightly higher than those of proven anti-lymphoma activity from $E$. coli and Er. carotovora, but 
Table 8. Effect of Crasnitin and Citrobacter asparaginase on the growth of Gardner lymphosarcoma

$\begin{array}{ccccc}\begin{array}{c}\text { Dose } \\ (\text { i.u. } / \mathrm{kg})\end{array} & \begin{array}{c}\text { Average } \\ \begin{array}{c}\text { survival time } \\ \text { (days) }\end{array}\end{array} & \begin{array}{c}\text { Increase in } \\ \text { life span } \\ (\%)\end{array} & \overbrace{\begin{array}{c}\text { Average } \\ \text { survival time } \\ \text { (days) }\end{array}}^{\text {Crasnitin }} & \begin{array}{c}\text { Increase in } \\ \text { life span } \\ (\%)\end{array} \\ 0 & 13.6 & - & 13.6 & - \\ 5 & 20.3 & 49 & 15.3 & 12.5 \\ 20 & >59.0 & \text { 'Cures' } & 22.0 & 62 \\ 80 & >59.0 & \text { 'Cures' } & >59.0 & \text { 'Cures' }\end{array}$

the activities of the Citrobacter enzyme at $\mathrm{pH} 7 \cdot 3$ (the $\mathrm{pH}$ of the mouse serum) and at $\mathrm{pH} 6.8$ (the $\mathrm{pH}$ of the mouse ascitic fluid) are 80 and $73 \%$ respectively of the maximum activity. This, and the low $K_{m}$ value, might explain the relative potency of the Citrobacter enzyme.

We thank Professor Sir Ernst Chain for interest and support during this work. We also thank the Pilot Plant staff for their assistance with large-scale fermentation and enzyme extraction, and Miss Angela Barker and Mr C. A. Grantham for skilled technical assistance. The work was supported by the Cancer Research Campaign.

\section{REFERENCES}

Arens, A., Rauenbusch, E., Irion, E., Wagner, O., Bauer, K. \& Kaufman, W. (1970). Isolation and properties of L-asparaginase from Escherichia coli. Hoppe-Seyler's Zeitschrift für physiologische Chemie 35I, 197-2I2.

Arima, K., Sakamoto, T., Araki, C. \& Tamura, G. (1972). Production of extracellular L-asparaginases by microorganisms. Agricultural and Biological Chemistry 36, 356-36I.

Banks, G. T., Mantle, P. G. \& Szczyrbak, C. E. (1974). Large-scale production of clavine alkaloids by Claviceps fusiformis. Journal of General Microbiology 82, 345-361.

Bascomb, S. \& Grantham, C. A. (1975). Application of automated assay of asparaginase and other ammoniareleasing enzymes to the identification of bacteria. In Some Methods for Microbiological Assay, Society for Applied Bacteriology Technical Series No. 8, pp. 29-54. Edited by R. G. Board and D. W. Lovelock. London and New York: Academic Press.

Bascomb, S., LAPAGE, S. P., CURTIS, M. A. \& Willcox, W. R. (1973). Identification of bacteria by computer: identification of reference strains. Journal of General Microbiology 77, 29I-3I 6.

Bettelheim, K. A., Kissin, E. A. \& Thomas, A. J. (1970). An automated technique for the determination of ammonia produced by bacteria. In Automation, Mechanisation and Data Handling in Microbiology, Society for Applied Bacteriology Technical Series No. 4, pp. I33-136. Edited by A. Baillie and R. J. Gilbert. London and New York: Academic Press.

Cammack, K. A., Marlborough, D. I. \& Miller, D. S. (1972). Physical properties and subunit structure of L-asparaginase isolated from Erwinia carotovora. Biochemical Journal 126, 36I-379.

Capizzi, R. L., Bertino, J. R. \& Handschumacher, R. E. (1970). L-Asparaginase. Annual Review of Medicine 2I, 433-444.

Cedar, H. \& Schwartz, J. H. (1968). Production of L-asparaginase II by Escherichia coli. Journal of Bacteriology 96, 2043-2048.

Clarkson, B., Krakoff, I., Burchenal, J., Karnofsky, D., Golbey, R., Oettgen, H., Dowling, M. \& Lipton, A. (1970). Clinical results of treatment with $E$. coli L-asparaginase in adults with leukemia, lymphoma and solid tumours. Cancer 25, 279-305.

CONNORS, T. A. \& JONEs, M. (1970). The effect of asparaginase on some animal tumours. Recent Results in Cancer Research 33, 18I-187.

COONEY, D. A. \& DAVIS, R. D. (1970). The stability of L-asparaginase with respect to protein denaturants. Biochimica et biophysica acta 212, 134-138. 
COONEy, D. A. \& HANDSChUmaCheR, R. E. (1970). L-Asparaginase and L-asparagine metabolism. Annual Review of Pharmacology ro, 42 I-440.

CoOper, C. M., Fernstorm, G. A. \& Miller, S. A. (1944). Performance of agitated gas-liquid contactors. Industrial and Engineering Chemistry 36, 504-509.

CrowTHER, D. (197I). L-Asparaginase and human malignant disease. Nature, London 229, I68-171.

Ho, P. P. K., Milikin, E. B., Bobbitt, J. L., Grinnan, E. L., Burck, P. J., Frank, B. H., Boeck, L. D. \& SQuires, R. W. (1970). Crystalline L-asparaginase from Escherichia coli в. I. Purification and chemical characterization. Journal of Biological Chemistry 245, 3708-3715.

HofsteE, B. H. J. (1959). Non-inverted versus inverted plots in enzyme kinetics. Nature, London 184, I 2961298.

HowaRd, J. B. \& CARPENTER, F. H. (1972). L-Asparaginase from Erwinia carotovora. Substrate specificity and enzymatic properties. Journal of Biological Chemistry 247, 1020-1030.

Imada, A., Igarasi, S., Nakahama, K. \& Isono, M. (1973). Asparaginase and glutaminase activities of micro-organisms. Journal of General Microbiology 76, 85-99.

Jayaram, H. N., Ramakrishnan, T. \& Vaidyanatham, C. S. (1968). L-Asparaginase from Mycobacterium tuberculosis strains $\mathrm{H}_{37} \mathrm{R}_{\mathrm{V}}$ and $\mathrm{H}_{\mathrm{i} 7} \mathrm{R}_{\mathrm{a}}$. Archives of Biochemistry and Biophysics 126, $165-174$.

$\mathrm{KoCH}$, F. C. \& MCMeEKIN, T. L (1924). A new direct Nesslerization micro-Kjeldahl method and a modification of the Nessler-Folin reagent for ammonia. Journal of the American Chemical Society 46, 20662069.

LAW, A. S. \& Wriston, J. C., JUn. (1971). Purification and properties of Bacillus coagulans L-asparaginase. Archives of Biochemistry and Biophysics 147, 744-752.

MASHBURn, L. T. \& WRISTON, J. C., JUn. (I964). Tumour inhibitory effect of L-asparaginase from Escherichia coli. Archives of Biochemistry and Biophysics 105, 450-452.

Miles, A. A. \& MisRA, S. S. (1938). The estimation of the bactericidal power of the blood. Journal of Hygiene $38,732-748$.

Peterson, R. E. \& Ciegler, A. (I969). L-Asparaginase production by Erwinia aroideae. Applied Microbiology 18, 64-67.

RedDY, V. V. S., JAYARAM, H. N., SIRSI, M. \& RAMAKRISHNAN, T. (1969). Inhibitory activity of L-asparaginase from Mycobacterium tuberculosis on Yoshida ascites sarcoma in rats. Archives of Biochemistry and Biophysics 132, 262-267.

RoberTs, A. N. \& SHEPHERD, P. G. (1968). Dissolved oxygen measurement in continuous aseptic fermentation. Process Biochemistry, February, 23-24.

Roberts, J., Burson, G. \& HiLl, J. M. (I968). New procedures for purification of L-asparaginase with high yield from Escherichia coli. Journal of Bacteriology 95, 21 1 7-2 I 23.

RoBerTS, J., Holcenberg, J. S. \& Dolowy, W. C. (1970). Antineoplastic activity of highly purified bacterial glutaminases. Nature, London 227, I $136-1137$.

ROBerTS, J., HolCENBERG, J. S. \& DolowY, W. C. (1972). Isolation, crystallization and properties of Achromobacteraceae glutaminase-asparaginase with antitumour activity. Journal of Biological Chemistry 247, 84-90.

Rowley, B. \& WRISTON, J. C., JUN. (1967). Partial purification and antilymphoma activity of Serratia marcescens L-asparaginase. Biochemical and Biophysical Research Communications 28, 160-165.

SaChS, D. H. \& PainTer, E. (1972). Improved flow rates with porous Sephadex gels. Science, New York 175 , $78 \mathrm{I}-782$.

Schwartz, J. H., Reeves, J. Y. \& Broome, J. D. (I966). Two L-asparaginases from E. coli and their action against tumours. Proceedings of the National Academy of Sciences of the United States of America 56, I5I6-I5I9.

SkARSTedt, M. T. \& Bascomb, S. (1974). Calcium hydroxyapatite fractionation as a second ion exchange step in protein purification: improvement of flow rate and resolution. Analytical Biochemistry 59, 16-23.

Tallal, L., Tan, C., Oettgen, H., Wollner, N., McCarthy, M., Helson, L., Burchenal, J., KarnofSKY, D. \& MURPHY, M. L. (1970). E. coli L-asparaginase in the treatment of leukemia and solid tumours in I3I children. Cancer 25, 306-320.

Tosa, T., Sano, R., Yamamoto, K., Nakamura, M., Ando, K. \& Chibata, I. (I97I). L-Asparaginase from Proteus vulgaris. Applied Microbiology 22, 387-392.

Tusa, T., Sano, R., Yamamoto, K., Nakamura, M. \& Chibata, I. (1972). L-Asparaginase from Proteus vulgaris. Purification, crystallization and enzymic properties. Biochemistry Ir, 21 7-222.

Wade, H. E., Elsworth, R., Herbert, D., Deppie, J. \& Sargeant, K. (1968). A new L-asparaginase with antitumour activity. Lancet ii, $776-777$. 
WADE, H. E., RoBINSON, H. K. \& PHILLIPS, B. W. (I97I). Asparaginase and glutaminase activities of bacteria. Journal of General Microbiology 69, 299-312.

WISE, W. S. (I95I). The measurement of the aeration of culture media. Journal of General Microbiology $5,167$. Wriston, J. C., JUN. (I97I). L-Asparaginase. In The Enzymes, 3rd edn, vol. 4, pp. IOI-I2I. Edited by P. D. Boyer. London and New York: Academic Press.

Wriston, J. C., JUN. \& YelLin, T. O. (I973). L-Asparaginase: a review. In Advances in Enzymology, vol 39 pp. I 85-248. Edited by A. Meister. New York: John Wiley. 